\title{
Complete migration of a composite mesh into small bowel incidentally found during laparotomy for colectomy in an asymptomatic patient: a case report
}

\author{
Pramodh Chandrasinghe ${ }^{1 *}$ (D) Asantha De Silva ${ }^{2}$, Ayomi Welivita ${ }^{3}$ and Kemal Deen ${ }^{3}$
}

\begin{abstract}
Background: Composite meshes are used for incisional hernia repair because they enable intraperitoneal mesh placement due to their dorsal surface, which is made of inert material. We report, for the first time, to our knowledge, a case of composite mesh migration detected incidentally during a laparotomy for colon cancer in an asymptomatic patient.

Case presentation: Our patient was a 71-year-old South Asian man who underwent ventral mesh repair following a postoperative complication after right hemicolectomy for colon cancer. The patient was diagnosed with a metachronous sigmoid cancer 5 years later, for which he underwent laparotomy. During laparotomy, a migrated mesh was incidentally found and extracted from his proximal ileum without any evidence of abscess or fistula formation.

Conclusion: To our knowledge, this is the first report of an incidentally found migrated composite mesh from a bowel lumen in an asymptomatic patient.
\end{abstract}

Keywords: Mesh migration, Composite mesh, Case report, Mesh complications

\section{Background}

Use of mesh has become standard in a majority of incisional hernia repair to achieve a tension-free repair and reduce recurrence [1]. The composite mesh is designed to reduce the risk of bowel adhering to the mesh by including an absorbable layer to one surface, enabling intraperitoneal mesh placement [2]. It is supposed to reduce complications such as mesh erosion into bowel caused by the use of intraperitoneal polypropylene-only meshes. Reports of mesh migration, both composite and nonabsorbable types, are found in the literature,

\footnotetext{
* Correspondence: pramodh@kln.ac.lk

'Department of Surgery, Faculty of Medicine, University of Kelaniya, Ragama, Sri Lanka

Full list of author information is available at the end of the article
}

although they are always associated with apparent clinical signs and symptoms such as abscess formation, enterocutaneous fistula formation, or bowel obstruction $[3,4]$. We report a case of a composite mesh completely migrating into the small bowel found during laparotomy for an unrelated issue.

\section{Case presentation}

A 71-year-old South Asian man who had under gone a right hemicolectomy for an adenocarcinoma of the colon was found to have a metachronous cancer in the sigmoid colon during surveillance colonoscopy. Following his primary surgery at another institution, he has developed an anastomotic leak during the immediate postoperative period, for which a second laparotomy had

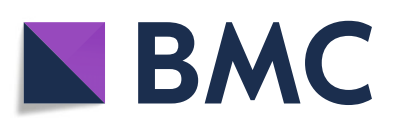

(c) The Author(s). 2020 Open Access This article is licensed under a Creative Commons Attribution 4.0 International License, which permits use, sharing, adaptation, distribution and reproduction in any medium or format, as long as you give appropriate credit to the original author(s) and the source, provide a link to the Creative Commons licence, and indicate if changes were made. The images or other third party material in this article are included in the article's Creative Commons licence, unless indicated otherwise in a credit line to the material. If material is not included in the article's Creative Commons licence and your intended use is not permitted by statutory regulation or exceeds the permitted use, you will need to obtain permission directly from the copyright holder. To view a copy of this licence, visit http://creativecommons.org/licenses/by/4.0/ The Creative Commons Public Domain Dedication waiver (http://creativecommons.org/publicdomain/zero/1.0/) applies to the data made available in this article, unless otherwise stated in a credit line to the data. 
been performed on day 5 with a revision of the anastomosis. During the first postoperative week, he had developed an enterocutaneous fistula with primary wound failure. His case was then taken over by the authors for the management of the fistula, which was done nonoperatively. Spontaneous healing of the fistula took 10 months, after which the patient underwent an abdominal wall reconstruction with an inlay polypropylene/polyglactin 910 composite mesh. The reconstruction was done 16 months after the primary surgery, and the mesh was fixed using polypropylene sutures. The patient remained asymptomatic until he was diagnosed with a sigmoid cancer on the basis of surveillance colonoscopy 5 years after the primary event. Following histological confirmation and staging with contrast-enhanced computed tomography, he was scheduled for laparotomy with subtotal colectomy and ileorectal anastomosis. During surgery, several loops of bowel were found to be tightly adherent to the anterior abdominal wall. On palpation, a hard, elongated mass was felt inside one of the bowel loops in the proximal ileum. After separating the loops from the posterior rectus sheath, an enterotomy was made to find the mesh inside the bowel lumen (Fig. 1). The mesh was not adherent to the bowel wall and could be extracted without difficulty. It was heavily deposited with fecal matter, indicating that it had been in the bowel lumen for a long period (Fig. 2). There was no evidence of an abscess, fistula, or sinus formation in the surrounding area. The enterotomy was closed with a side-to-side stapler anastomosis, and the patient underwent subtotal colectomy with ileorectal anastomosis with an uneventful recovery.

\section{Discussion}

There have been few cases of composite mesh migration reported in the literature, although the patients have been symptomatic in every instance, with a complication such as enterocutaneous fistula, bowel obstruction, or intra-abdominal mass formation $[3,5,6]$. To our knowledge, this is the first report of a composite mesh migration without causing symptoms or signs. Herrera et al. reported the first case of mesh migration following incisional hernia repair [7]. A foreign body laying inside the peritoneal cavity has the tendency to migrate into bowel or through the skin into the exterior. Composite meshes were designed to eliminate this by having a more porous nonabsorbable surface facing anteriorly to allow ingrowth of connective tissue while the inert surface made of an absorbable material faces inside, preventing adhesions [2]. The migration process may occur either acutely due to a postoperative inflammatory process or as a slow process [8]. It is possible that the initial event in our patient was the dislodgment of the mesh from the anchoring sutures. Several small bowel loops could have adhered to the exposed polypropylene surface, and slow erosion into a loop would have started. The initial necrosis of the bowel wall due to the inflammation would have been sealed off by the surrounding bowel loops, preventing an abscess formation. Once the mesh was slowly internalized, it is possible that the opening would simultaneously have been sealed off by the bowel loops; hence, the

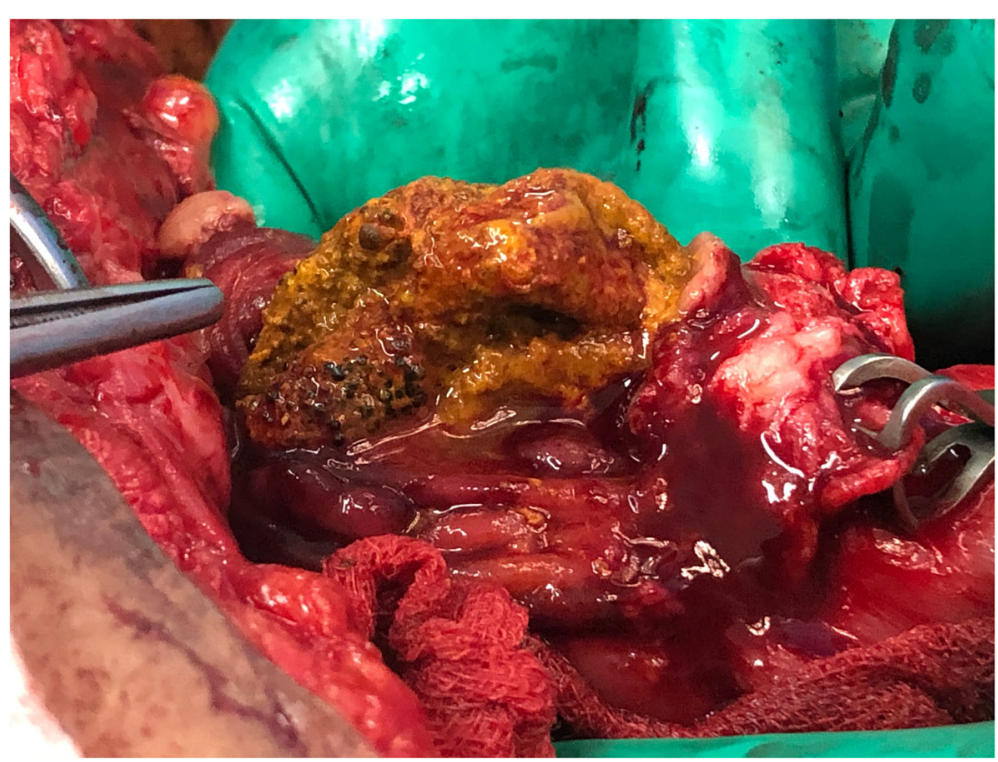

Fig. 1 The migrated mesh inside the proximal ileum seen through the enterotomy 


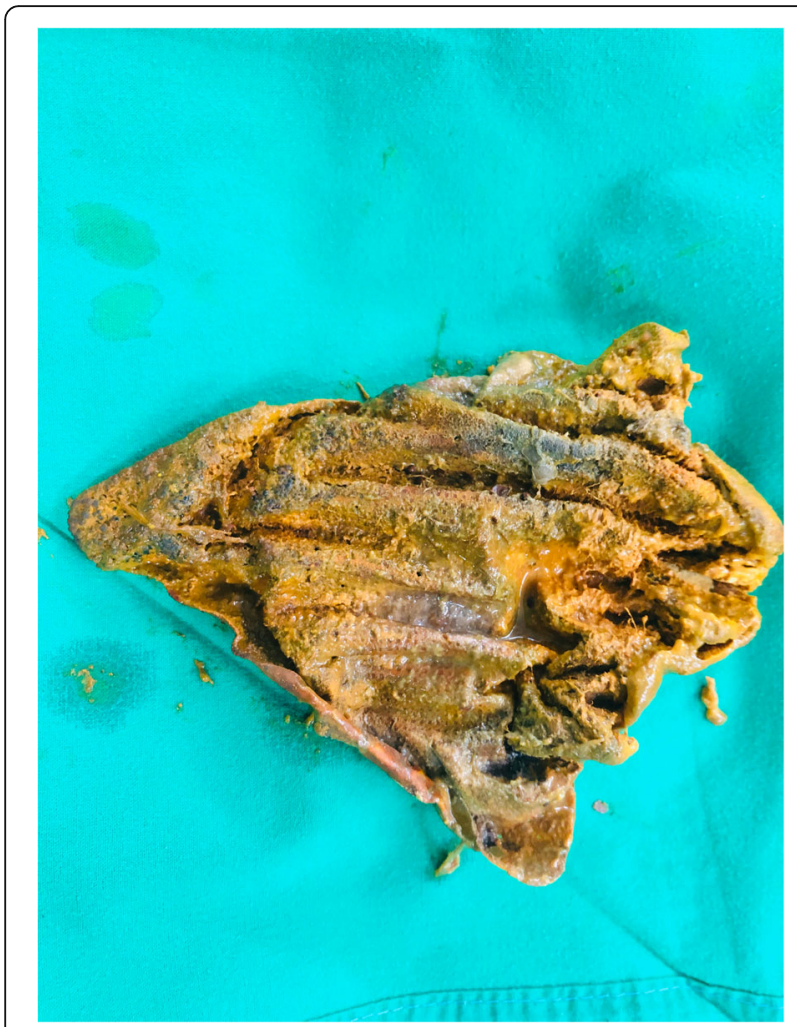

Fig. 2 The extracted mesh with heavy deposition of fecal matter

bowel mass detected during this laparotomy would have formed. Similar silent erosion by a retained surgical sponge has been reported [9]. A slow process is likely to cause foreign body migration without leakage of content, but, given the size of the extracted mesh, it is highly likely to cause a fistulous tract. Soler et al. reported one case of composite mesh migration into the small bowel under experimental conditions in a murine study [10]. Mesh migration to different parts of the intestine in humans has been reported $[3,7,11,12]$. In all cases, the patients were symptomatic due to sepsis or obstruction. The uniqueness of our patient's case is that at no stage during the preceding 4 years had the patient experienced such a complication. The staging computed tomography $(\mathrm{CT})$ performed in this patient did not reveal the presence of a mesh in the small bowel. The literature also indicates similar failures of $\mathrm{CT}$ scans to detect the presence of a mesh inside the bowel [3].

\section{Conclusion}

Incisional hernia repair involves the use of novel mesh devices designed to reduce complications. Composite meshes are designed to prevent bowel adhesion by using an inert material to the dorsal surface, although several cases of mesh migration have been reported. Reports of composite mesh migration are all associated with patients presenting with either infective or obstructive symptoms. This case report, for the first time, to our knowledge, raises the possibility of complete migration of a composite mesh without causing symptoms or signs.

\section{Abbreviations \\ CT: Computed tomography}

\section{Acknowledgements \\ We thank the patient for providing consent to publish.}

\section{Authors' contributions}

$\mathrm{PC}, \mathrm{ADS}, \mathrm{AW}$ and $\mathrm{KD}$ were involved in direct patient care and conceptual development of the report. PC was involved in writing the manuscript. PC, ADS, AW and KD were involved in the review, critical appraisal, and correction of the manuscript. All authors read and approved the final manuscript.

\section{Funding}

No funding was acquired.

Availability of data and materials

Available on reasonable request.

Ethics approval and consent to participate

This study was conducted in accordance with the fundamental principles of the Declaration of Helsinki.

\section{Consent for publication}

Written informed consent was obtained from the patient for publication of this case report and any accompanying images. A copy of the written consent is available for review by the Editor-in-Chief of this journal.

\section{Competing interests}

The authors declare that they have no competing interests.

\section{Author details}

'Department of Surgery, Faculty of Medicine, University of Kelaniya, Ragama, Sri Lanka. ${ }^{2}$ Department of Obstetrics and Gynecology, Faculty of Medicine, University of Kelaniya, Ragama, Sri Lanka. ${ }^{3}$ Kings Hospital, Colombo 5, Sri Lanka.

Received: 6 August 2020 Accepted: 21 September 2020

Published online: 31 October 2020

\section{References}

1. Luijendijk RW, Hop WC, van den Tol MP, de Lange DC, Braaksma MM, IJzermans $\mathrm{JN}$, et al. A comparison of suture repair with mesh repair for incisional hernia. N Engl J Med. 2000;343(6):392-8.

2. Gonzalez R, Rodeheaver GT, Moody DL, Foresman PA, Ramshaw BJ. Resistance to adhesion formation: a comparative study of treated and untreated mesh products placed in the abdominal cavity. Hernia. 2004;8(3): 213-9.

3. Bostanci O, Idiz UO, Yazar M, Mihmanli M. A rare complication of composite dual mesh: migration and enterocutaneous fistula formation. Case Rep Surg. 2015;2015:293659.

4. Manzini G, Henne-Bruns D, Kremer M. Severe complications after mesh migration following abdominal hernial repair: report of two cases and review of literature. GMS Interdiscip Plast Reconstr Surg DGPW. 2019;8: Doc09.

5. Gandhi D, Marcin S, Xin Z, Asha B, Kaswala D, Zamir B. Chronic abdominal pain secondary to mesh erosion into cecum following incisional hernia repair: a case report and literature review. Ann Gastroenterol. 2011;24(4): $321-4$.

6. Yilmaz I, Karakas DO, Sucullu I, Ozdemir Y, Yucel E. A rare cause of mechanical bowel obstruction: mesh migration. Hernia. 2013;17(2):267-9.

7. Herrera MA, Hsia TW, Becker DR. Migration of Teflon mesh from abdominal wall into large bowel. N Y State J Med. 1976;76(3):452-3.

8. Agrawal A, Avill R. Mesh migration following repair of inguinal hernia: a case report and review of literature. Hernia. 2006;10(1):79-82. 
9. Choi JW, Lee CH, Kim KA, Park CM, Kim JY. Transmural migration of surgical sponge evacuated by defecation: mimicking an intraperitoneal gossypiboma. Korean J Radiol. 2006;7(3):212-4.

10. Soler M, Verhaeghe P, Essomba A, Sevestre H, Stoppa R. Treatment of postoperative incisional hernias by a composite prosthesis (polyesterpolyglactin 910): clinical and experimental study [in French]. Ann Chir. 1993; 47(7):598-608.

11. Millas SG, Mesar T, Patel RJ. Chronic abdominal pain after ventral hernia due to mesh migration and erosion into the sigmoid colon from a distant site: a case report and review of literature. Hernia. 2015;19(5):849-52.

12. Nelson EC, Vidovszky TJ. Composite mesh migration into the sigmoid colon following ventral hernia repair. Hernia. 2011;15(1):101-3.

\section{Publisher's Note}

Springer Nature remains neutral with regard to jurisdictional claims in published maps and institutional affiliations.

Ready to submit your research? Choose BMC and benefit from:

- fast, convenient online submission

- thorough peer review by experienced researchers in your field

- rapid publication on acceptance

- support for research data, including large and complex data types

- gold Open Access which fosters wider collaboration and increased citations

- maximum visibility for your research: over $100 \mathrm{M}$ website views per year

At $\mathrm{BMC}$, research is always in progress.

Learn more biomedcentral.com/submissions 